Journal of Law and Religion 33, no. 2 (2018): I29-133 (C) Center for the Study of Law and Religion at Emory University doi:I0.IOI7/jlr.20I 8.30

\title{
EDITORIAL
}

It is a stock phrase in many international relations circles that when the United States sneezes, the world catches a cold. The contagion theory is one that could apply to each of the two symposia that make up this issue, but in different ways. The first symposium, the "Legitimate Scope of Religious Establishment," comes to us from a conference of that name held in Venice in 20I6. The essays here, just a sample of the conference offerings, describe issues of religious establishment in the United States, Italy, and Argentina. It will be followed in a subsequent issue by additional articles on religious establishment around the world. The second symposium, "The Bureaucracy of Religion in Southeast Asia," describes how religion is managed and regulated by the state in Thailand, Malaysia, Brunei, Singapore, and Indonesia.

When it comes to religious establishment, the US Constitution's admonition that "Congress shall make no law establishing religion" was the disestablishment sneeze heard around the world. In addition to casting off British colonial oppression, the Constitution's framers were casting off the Caesaropapist model of religious establishment, with the monarch as head of both church and state, that persists to the present day. But the global picture is more complicated. Socially secular Europe maintains curiously high levels of religious establishment and state churches, even as many socially religious, postcolonial nations in Africa, Asia, and Latin America-the Global South-wasted no time after independence in drafting constitutional provisions against state religions, or even declaring themselves to be "secular" states. Notable exceptions in Africa include the nation of Zambia, which declared and has repeatedly reaffirmed its status as a "Christian nation," along with Liberia, which has also flirted with the Christian nation concept. In the Asia Pacific region, just last year, the island nation of Samoa adopted the "Christian nation" designation. So, clearly, religious establishment is not exclusively a European concern, as can be seen in current discourse over proclaimed and proposed "Islamic states" across the Muslim world today.

Indeed, there is a fine line between religious management and religious establishment in many parts of the world today, with many of those regions being largely immune from the American disestablishment bug. In Southeast Asia, the eyes of many nations in the region are currently focused on Indonesia, which has struggled in recent years to balance concerns about Islamism and terrorism as threats to its development with democracy and pluralism. It is a fertile petri dish of experimentation in configurations of religious establishment and religious bureaucracy.

In US Constitutional jurisprudence, the force of the Establishment Clause, prominently litigated in such matters as civic and school prayer, has been perceived to have waned somewhat in recent years. It is as if the Religious Freedom Restoration Act, the International Religious Freedom Act, various state-level religious freedom measures, and the Free Exercise Clause of the Constitution have taken up much of the jurisprudential oxygen in the room, leaving the Establishment Clause and the very real problems of state endorsement of and entanglement with religion to suffocate in a corner. At the same time, some parts of the world, mostly notably in the laïcité that characterizes France, Québec, and parts of francophone West Africa, have seen the development of particularly hard forms of disestablishment, which in demanding that the state enforce the absence of religious symbols, messages, and other manifestations, ironically make the state the greatest intruder into religion, in the name of "liberty, equality, and fraternity." In this way, it can be 
said that laïcité itself becomes a form and means of establishment, entailing rigorous management of religion by the state.

In an influential volume of essays edited by Winnifred Fallers Sullivan and Lori G. Beaman, titled Varieties of Religious Establishment (Farnham: Ashgate, 2013), the authors grapple with the idea that religious establishment, rather than religious freedom, should be a focus for understanding the role of religion in public life. The argument has merit, as much-discussed Pew Research Center statistics have in recent years shown continuing escalation of government restrictions on religion, as well as government involvement in social hostilities around religion through active facilitation or neglect to intervene-hostilities which then become the state's responsibility to manage. Indeed, management of religion has become an important area of study in law and religion-and in matters of religious freedom - as states continue to crack down on some religions in ways that may directly or indirectly benefit others or actually engage in doling out benefits to favored religious, who then risk losing their independence and serving as handmaids to the state. Religion management may have a certain practical appeal in parts of the world threatened with religious conflict or where partnerships with religious groups in areas such as health care or education can relieve the state of some of its obligations-but religion management can also serve as a softer form of religious establishment.

In his article in the "Legitimate Scope of Religious Establishment" symposium, Brett Scharffs takes up the myth of the "uniqueness" of the United States Establishment Clause. ${ }^{\mathrm{I}}$ Reviewing the history of separationist and accommodationist impulses in American religion jurisprudence, Scharffs provocatively argues that there has been a "general ascendance of equality and nondiscrimination norms above liberty and nonentanglement norms in American political life." ${ }^{2}$ This seems consistent with the related observation that free exercise claims are increasingly framed in terms of free speech and liberty of conscience. Particularly in the joinder of such conscience claims with equality and nondiscrimination principles, we may be seeing calls for a new form of religion management to adjudicate these claims in American jurisprudence and American public life. The point at which religion management becomes religious establishment, constituting state support for particular religions or religion itself would then need determination.

Matteo Visioli addresses the religious establishment issue through the lens of "state confessionalism" in Italy and other parts of Catholic Europe. Visioli focuses particularly on understandings of confessionalism set forth at the Second Vatican Council. He describes Catholics as living in a "double system," in which they are called to "participate in the national sphere by virtue of a citizenship that makes them subjects of rights and duties" but also "belong to the church on the basis of the baptism that makes each one of them a person inside the church." ${ }^{3}$ That dual status, Visioli argues, has the effect of "granting them a peculiar legal capacity and, in most cases, the ability to act." But such action does not require support in the form of a hard form of religious establishment. Indeed, Visioli recommends, "The state and the church should not simply operate within the same environment, but rather as mutual allies. The state and the church are independent from each other; the church offers the state its own contribution for the good of its believers, thereby fostering the right to religious freedom, while the state allows the church to deliver its mission through its own institution, without which it could not operate. In order to accomplish these goals, all that

I Brett G. Scharffs, “The (Not So) Exceptional Establishment Clause of the United States Constitution,” Journal of Law and Religion 33, no. 2 (2019) (this issue).

2 Scharffs, "The (Not So) Exceptional Establishment Clause."

3 Matteo Visoli, "The Catholic Church Tested for Confessionalism: The Vatican II Doctrinal Principles," Journal of Law and Religion 33, no. 2 (2019) (this issue). 
is needed is a free cooperation between the two, not the establishment of the church as the official religion of the state." 4

As an Argentine, Juan Martin Vives traverses both the American and the Latin worlds - and the topic of his article well reflects this geographical overlap. Vives describes how the Constitution of Argentina recognizes the right of free exercise of religion, but also preserves a place of privilege for the Catholic Church, including financial support. Vives also describes the particular plight of Argentina's religious minorities, since Argentina, with other Latin American nations is no longer a Catholic religious monoculture. Identifying key questions now percolating around religious establishment in multicultural societies, Vives notes that within the context of pluralism, "The most contentious issues have arisen when the use of public space is at stake. In a democratic, pluralistic society, the conflict arising from the exercise of a positive freedom of some and the negative freedom of others 'cannot be resolved through the principle of the majority, because the fundamental right to freedom of beliefs involves, in a special way, respect for minorities.' In such circumstances, therefore, the negative freedom of minorities should be preferred." 5

How to balance separation and accommodation, a religiously managerial state with church autonomy, the dual roles of citizen and believer, freedom of religion with rights of nonbelievers to be free from imposition or coercion from the beliefs of others, and how to balance claims of "liberty of conscience," religious and otherwise, with principles of equality and nondiscriminationthese are the ongoing issues in demarcating the legitimate scope of religious establishment. Religious freedom may have fully occupied the space of religious jurisprudence in recent decades, but as these essays and others around the field of law and religion attest-religious establishment is back!

If the American disestablishmentarian revolution shook the eighteenth-century world, a bureaucratic revolution seems to be spreading across many religion-state contexts in Southeast Asia. This bureaucratization of religion is taking place against the background of recent struggles to maintain economic development, democratic stability, and vibrant religious pluralism in the region. The second symposium in this issue, "The Bureaucratization of Religion in Southeast Asia," takes up these issues. "Bureaucratization" is a term most frequently associated with the thought of nineteenthcentury German sociologist Max Weber, whose understanding of the meaning and implications of bureaucratization are both affirmed and challenged in several articles in this symposium.

Tomas Larsson's article on bureaucratization and protection of Thai Buddhism and its implications for religious freedom departs from the observation that "Thai rulers have felt obliged to devote considerable energies towards the promotion and protection of Buddhism." ${ }^{6}$ In the aftermath of the 20I4 military coup in Thailand, Larsson argues that more recent and concerted efforts at strengthening Buddhism can be understood, partially, as an "authoritarian regime's attempt to win religious legitimacy by doing something 'good' for the country's majority religion." But in Larsson's view, the new impetus to strengthen Thai Buddhism also reflects the "perception, common among conservative state elites and their middle-class supporters, that the political 'corruption' and violent turmoil that Thailand has suffered over the past fifteen years have been caused

4 Visoli, "The Catholic Church Tested for Confessionalism."

5 Juan Martin Vives, "Religious Freedom without Equality? Religious Minorities and the Establishment of Religion in Argentina," Journal of Law and Religion 33, no. 2 (2019) (this issue), quoting María Angélica Gelli, Constitución de la Nación Argentina: Comentada y Concordada [Constitution of the Argentine Nation, with commentary and annotation], 4th ed. (Buenos Aires: La Ley, 2008), I77-78.

6 Tomas Larsson, "Buddhist Bureaucracy and Religious Freedom in Thailand," Journal of Law and Religion 33 , no. 2 (2019) (this issue). 
in no small part by a corresponding corruption of the moral base of Thai society." In this context, Larsson argues, "Religious reforms intended to 'strengthen' institutional Buddhism are thus seen as providing a means by which Thai society can be inoculated against the dangers of democracy." 7 This impetus has led the Thai government to adopt programs focused on reform of the governance of religion, the analysis of which is the focus of Larsson's article.

Dominik M. Müller's article examines the overall theme of the "bureaucratization of Islam" in Southeast Asia, with specific focus on the tiny nation of Brunei Darussalam and the island nation of Singapore. Müller's study focuses on Brunei and Singapore as nations where Islam plays a politically active role. In what Müller characterizes, overall, as a dearth of scholarly research on bureaucratization of religion in Southeast Asia, his argument focuses on bureaucratization of Islam as "formalization, expansion, and diversification of Islamic institutions, but as a much wider social and cultural phenomenon that transcends its organizational boundaries." ${ }^{8}$ This more social and human, as opposed to merely administrative, perspective on bureaucracy is, Müller argues, a challenge to the traditional understanding put forth by Max Weber, "for whom bureaucracy was incompatible with sincere and passionate religiosity on part of the bureaucrats (although they may strategically exploit religion), let alone empowering public religiosity." 9 So, the status of religion itself seems to be enhanced in this new religious bureaucratic framework, but under an authoritative or authoritarian state, this can have negative consequences for religion and state alike. A key question of Müller's article is whether Brunei and Singapore, in their management of religion have exemplified authoritarian tendencies.

In analyzing the political origins of Islamic courts in Malaysia, Kikue Hamayotsu, adopts a more standard Weberian perspective in focusing on the bureaucratization of the institutional system of the religious courts. Unlike other Muslim-majority states, Malaysia is one, Hamayotsu tells us, in which the "place of Islamic courts and laws in a modern state is generally a source of conflict among political and religious elites." and systems for accommodating religion and religious institutions among Malaysia's states. As a result, Hamayotsu argues, "the power, authority, and legitimacy of the Islamic courts and judges have been dramatically upgraded to a level closer to the secular courts and judges, which historically had enjoyed more prestige." Indeed, Hamayotsu argues, "the interests-and strategic coalitions-of political and religious elites within the majority community to sustain a dominant regime and majoritarian rule based on communal identity are key to understand why the Malaysian Islamic court system was expanded and successively integrated into the nominally secular judiciary over time.” ${ }^{\mathrm{I}}$

Stewart Fenwick discusses the shift from "deconfessionalized" to "confessionalized" Islam in his examination of Indonesia's national ulama council-a shift that has manifested to the state and legal response to Islam, as well. The "deconfessionalization" was thought to have been an achievement and manifestation of the "overarching power of government and the bureaucracy," but this has been transmogrified since Indonesia's 1998 democratization into a situation in which the ulama council has increased its power, becoming the mouthpiece of Islam in relation to the state and

7 Larsson, "Buddhist Bureaucracy and Religious Freedom in Thailand."

8 Dominik M. Müller, "Bureaucratic Islam Compared: Classificatory Power and State-ified Religious Meaning-Making in Brunei and Singapore," Journal of Law and Religion 33, no. 2 (2019) (this issue).

9 Müller, "Bureaucratic Islam Compared."

Io Kikue Hamayotsu, "The Political Origins of Islamic Courts in Divided Societies: The Case of Malaysia,” Journal of Law and Religion 33, no. 2 (2019) (this issue).

I I Hamayotsu, "The Political Origins of Islamic Courts in Divided Societies." 
effectively annexing itself to the state. As Fenwick observes, this has raised "fundamental questions about the purpose and structure of the state, and the role of a religious authority in public administration, as well as the meaning of religious freedom in democratized Indonesia." ${ }^{2}$ In a pattern that contributors to this issue's other symposium, "The Legitimate Scope of Religious Establishment," would certainly recognize, these developments have also had their effects on the religion of Islam, for Fenwick also notes that recent scholarly debate has focused on the "degree to which Islam has been bureaucratized due to the close embrace of religious functions by government administration and institutions." In this Indonesian religion-state dynamic, Fenwick further argues, the "Indonesian state's efforts to be seen to recognize Islamic practices as well as to graft them into the existing regulatory and bureaucratic systems" ${ }^{13}$ can be seen.

Eva Nisa's article also addresses the Indonesian religion-state relationship and context of bureaucratization, in the specific case of the practice of "secret" Muslim marriages conducted without state recognition. The regulation of marriage has been a key function of the state in societies from West to East, given the state's interest in determining who is married for administrative reasons and in service of the larger goal of promoting marital, familial, and social stability. The issue of "secret" Muslim marriages in Indonesia has brought women's rights activists, legal activists, religious leaders, and the state together in a debate over what to do. While some argue that these marriages should be subject to state registration and recognition as a matter of social reform, others argue that registration impedes minority understandings of religion, including the argument of some conservative Muslims that marriage should be regulated by religious leaders only, and not the state. In light of the importance of marriage for both religion and state, this bureaucratization of religious marriage has been staunchly resisted in some quarters of the Indonesian Muslim community in ways that provide an excellent case study in considering how far state bureaucratization should go.

What the articles in both symposia show is the ongoing negotiation over the relationship of religion and the state in societies ranging from the European and European-colonized regions in the New World, from which the United States eventually disarticulated itself in establishing constitutional foundations along more or less separationist lines, to Southeast Asia, an intensely religiously pluralistic region struggling to balance religion and democracy. The disestablishment impetus that so shaped the United States at its founding still seems "exceptional" compared to many parts of the world in which various schemas of establishment and bureaucratization still persist, and these regions are, thus, fertile areas for inquiry in the relationship of law, religion, and the state.

\section{Christian Green}

Co-editor, Journal of Law and Religion

Research Director for Law, Religion and Human Rights, Center for the Study of Law and Religion

I2 Stewart Fenwick, "Eat, Pray, Regulate: The Indonesian Ulama Council and the Management of Islamic Affairs," Journal of Law and Religion 33, no. 2 (2019) (this issue).

I3 Fenwick, "Eat, Pray, Regulate." 